\title{
OPINION
}

\section{THE WET ZONE RICE CULTURE IN SRI LANKA: A RATIONAL LOOK}

\author{
M. P. DHANAPALA \\ Technical Advisor, JICA - Tsukuba International Center, Ibaraki, Japan.
}

Accepted: 22 December 2005

Three decades ago, in 1970 s, when every morning we woke up, we had to think of feeding around 700 additional mouths. That was the trend in population growth at that time and the major emphasis was on increasing productivity of rice. Even though the current population growth rate has gone down considerably, we still have to feed a substantial number of additional mouths every day.

Despite this increase in demand for rice, we have no new land to be brought under the plough. The tsunami may also have taken a heavy toll on productive paddy land in the eastern and southern districts. Moreover, the extent of cultivated land is diminishing rapidly. Most of the paddy land in the wet zone are abandoned for one reason or another. For example, in the Gampaha District where I was born and brought up, more than eighty percent of the total extent of paddy land is lying fallow at present. This would be the general situation in the entire Wet Zone of the country. One of the major reasons for this has been quoted as the high literacy rate. The new generation also does not want to be farmers even if they belong to the rural farming community.

I can remember that once an Indian expert inquired about the literacy rate of Sri Lanka, to advise on sugarcane cultivation in the Inginimitiya Project. Hearing about the literacy rate of the country, his immediate response was "forget sugarcane at all". Although the literacy rate may have an effect on choosing agriculture as an occupation, there are other reasons for people to move away from rice farming.

Although inadequate maintenance of irrigation facilities has been identified by the farmers as a major reason to abandon paddy tracts, could it be the in the Wet Zone? With a cumulative annual rainfall of above $2000 \mathrm{~mm}$, the major problem in the wet zone appears to be drainage; and not lack of irrigation facilities. A farmer should cultivate at least one crop a year, the traditionally adopted system, with the proper timing of the season to avoid floods and drought spells. Undoubtedly the paddy land of the Wet Zone can be cultivated in both seasons. The low lying coastal belt of half bog and bog soils may experience inundation, floods and soil problems associated with anaerobic decomposition of organic matter. They may need location specific cultivation packages including appropriate cultivars. The inland valleys of $1^{\text {st }}$ order may have problems related to leaching Iron and Aluminum from the adjoining uplands. To improve the paddy yields of these tracts, the sub soil drainage has to be improved by having drainage/ irrigation channels dug deep on either side along the tracts, well below the field surface level, to contain emerging spring water (fluxial water) from the adjoining highland. The impact of provision of subsoil drainage has not been researched in Sri Lanka but, is a proven technology adopted in Japan in major paddy tracts.

Today, people are not willing to cultivate paddy if they have access to any other occupation. This is due to the simple reason that paddy cultivation is the least remunerative of all occupations. Historically the farmers cultivated paddy because of the social dignity and the pride they had in consuming rice which is grown locally. This situation existed for centuries and the counter measures taken to increase the income of the farmer had not been effective. The farmer and his labour were exploited for the benefit of others. This inherent parasitic behaviour has been detrimental to the farming community. This along with the increased literacy rate moved people away from agriculture, paddy cultivation in particular, with the belief that there is no future in it. 
It is worth examining the productivity of the rice crop since the late colonial regime, to understand the impact of innovative research. Besides, some learned people too have been critical about the research findings and have distorted the facts to make them appear attractive to the general public.

The progress made in the productivity of rice due to technological improvements was in quantum jumps. This was achieved by purification cultivars, modifying the architecture of the plant to use solar radiation efficiently in the photosynthetic process and to convert the majority of photosynthates to grain but not to straw. Simultaneously fertillizer efficiency and lodging resistance was incorporated in to the new cultivars. In the latter stages of rice research, tolerance to pests and diseases as well as the grain quality parameters were also improved. The whole process took place in a few steps which took nearly half a century, beginning from the traditional cultivars to pure-lines, old improved cultivars and new improved cultivars. Two more concepts, Uni-culm advantage and Hybrid vigour are being investigated presently by scientists as the next two known steps to improve productivity.

We always prefer Supersonic aeroplanes to what was developed by the Wright brothers, a Limousine to a Bullock cart or a Computer to an Abacus, but when it comes to agriculture the attitude is different. There has been much criticism regarding the new technological findings and recommendations of the local rice researchers.

Also it may be noted that many issues of the scientific journal, Tropical Agriculturist, (by Ceylon Agricultural Society) printed in the past, have mentioned the land extent and the total rice productivity during the terminal era of the colonial regime. Accordingly in 1940 s, when we had one third of the present population, we imported two thirds of the country's requirement of rice. The average rice yield was then less than 15 bushels per acre $(0.75 \mathrm{t} / \mathrm{ha})$. Today, the population has increased by a factor of three; the paddy land extent by a factor of 2 and the rice productivity by a factor of 5 . We import only 5 to 10 percent of the total requirement of rice. Yet we have not reaped the full potential of the modern rice cultivars. There is a gap between the real potential of modern rice cultivars and the realized farm yields, and this gap can be at least narrowed down if not eliminated completely. This is the most critical issue we are facing now. We act blindly to what is happening in other countries with regard to the production and consumtion of rice.

The market price of the cheapest rice I can afford in Japan is $¥ 178$ per $\mathrm{kg}$, the rupee equivalent of which is around Rs 155/=. A Thai groceries shop, a few kilometers away, sells their average quality rice at a rate of $260 / \mathrm{kg}$ even though Thai rice is much cheaper in their own country. These are fabulous prices from any Sri Lankan standards but the question remains as to why this is so. There should be some hidden tariff structure behind the whole issue to protect the local rice farmer and to safeguard the countries food security. If so why cannot we do the same.

On the other hand, there is a surplus in rice production in India. An Indian friend conveyed to me that in Eastern India alone, a surplus production of 14 million tons of milled rice is available. Their cost of production is lower than ours and rice is comparatively cheap. Our total annual requirement is less than two million tons of milled rice and India can very well provide that quantity at its production cost, without any impact on their economy. Who can assure that this would not happen? In such a situation, what would be the fate of the local rice farmer? One may interpret this as a lack of comparative advantage in rice production in our country, which India has. How do they produce cheap rice when the national average of rice yield is below ours? We have to study their subsidy structure, the emphasis they place on Boro rice production, the low/no cost electricity to pump underground water from shallow water table to irrigate Boro rice crop grown during the dry season; the exploitation of natural soil fertility renewed annually in the flood planes of big rivers flowing across the country; the incentives given to the farmers; the encouragement and recognition given to the rice scientists; the investments made in rice research, varietal improvement and acceptance of proven technologies by the community etc. 
Elaboration of a few of the above issues illustrates how the technologies and rice related policies would affect the farmer as well as the rice production in the Wet Zone in particular. By and large this is not a comprehensive account of what needs to be conveyed. There were few things beyond my comprehension while I was working as a rice breeder at the RRDI. In many instances when $I$ attended the farmer forums to discuss technical issues I never encountered problems pertaining to rice technology. Farmers had much more burning issues than technical ones. If I put them down in some order, the first would be irrigation related issues, the next is timely availability of inputs and cost of inputs, then comes the agricultural loans, credits and subsidies, then the damage by wild animals, specifically wild boar and finally the marketing issues, paddy prices etc. It is difficult to point a finger at any one on these issues because every one has a ready made pack of answers to remedy the problem. But the desperate appeal of the farmer is to solve these issues for him and it is a must that the policy makers should have a positive approach in solving them.

One must bear in mind that the technological issues would only come next to above issues. The Department of Agriculture has a field tested ready made package to bridge the yield gap to improve and sustain productivity in rice, which could be modified so as to suit the Wet Zone environment to improve rice productivity. Therefore if the above mentioned non-technological issues are not looked after immediately, the abandoning of paddy fields by farmers and the farming community moving away from paddy cultivation will be inevitable. 